\title{
Uwarunkowania i formy instytucjonalnej polsko-czeskiej współpracy transgranicznej \\ Conditioning and forms of institutional cooperation across the Polish-Czech border
}

\author{
Łukasz Lewkowicz (1) \\ Uniwersytet Marii Curie-Skłodowskiej, Wydział Politologii i Dziennikarstwa \\ pl. Litewski 3, 20-080 Lublin \\ lukasz.lewkowicz@poczta.umcs.lublin.pl
}

Zarys treści. Przemiany społeczno-polityczne w Europie Środkowej po 1989 r. umożliwiły rozwój współpracy transgranicznej Polski z państwami sąsiednimi. Jednym z ważniejszych partnerów współpracy dla polskich samorządów terytorialnych stała się Republika Czeska. Aktualnie pogranicze polsko-czeskie, obok polsko-niemieckiego i polsko-słowackiego, stanowi modelowy przykład innowacyjnej współpracy transgranicznej. Na tym obszarze powstały pierwsze w Polsce euroregiony, a następnie bardziej zaawansowane formy współpracy transgranicznej - europejskie ugrupowania współpracy terytorialnej. Dynamicznie rozwija się współpraca bilateralna poszczególnych samorządów terytorialnych. Wciąż jednak wydaje się, że współpraca transgraniczna w tym regionie posiada niewykorzystany potencjał. Celem niniejszego artykułu była analiza funkcjonujących obecnie na polsko-czeskim pograniczu podmiotów transgranicznych: euroregionów (Nysa, Glacensis, Pradziad, Silesia, Śląsk Cieszyński, Beskidy), europejskich ugrupowań współpracy terytorialnej (Tritia, Novum), wybranych jednostek samorządowych. Analiza podmiotów transgranicznych została przeprowadzona na trzech płaszczyznach: genetycznej, strukturalnej i funkcjonalnej. Dzięki przeprowadzonym badaniom możliwe było przedstawienie podobieństw i różnic pomiędzy wspomnianymi aktorami transgranicznymi, pokazanie ich specyfiki, perspektywy współpracy.

Słowa kluczowe: polsko-czeska współpraca transgraniczna, polsko-czeskie pogranicze, euroregion, europejskie ugrupowanie współpracy terytorialnej.

\section{Wstęp}

Przemiany społeczno-polityczne w Europie Środkowej po 1989 r. umożliwiły rozwój współpracy transgranicznej Polski z państwami sąsiednimi. Przyczyniła się do tego reaktywacja samorządu terytorialnego na szczeblu gminnym, a potem powiatowym i wojewódzkim. Intensyfikacja współpracy transgranicznej nastąpiła po przystąpieniu Polski i Czech do Unii Europejskiej w 2004 r., a następnie wejściu obu państw do strefy Schengen w 2007 r. Od początku lat 90. XX w. samorządy polskie podejmowały współpracę ze swoimi odpowiednikami po stronie czeskiej. Aktualnie pogranicze polsko-czeskie, obok polsko-niemieckiego i polsko-słowackiego, stanowi przykład dynamicznie rozwijającej się współpracy transgranicznej. Na tym obszarze powstały pierwsze w Polsce euroregiony, a następnie bardziej zaawansowane formy współpracy transgranicznej - europejskie ugrupowania współpracy 
terytorialnej. Dynamicznie rozwija się również współpraca bilateralna poszczególnych samorządów terytorialnych.

Celem niniejszego artykułu jest analiza instytucjonalna polsko-czeskiego pogranicza. Obecnie na obszarze tym funkcjonuje 8 podmiotów transgranicznych: 6 euroregionów (Nysa, Glacensis, Pradziad, Silesia, Śląsk Cieszyński, Beskidy) i 2 europejskie ugrupowania współpracy terytorialnej (Tritia, Novum). W artykule zawarto część teoretyczną objaśniającą istotę współpracy transgranicznej i euroregionalnej przedstawione zostały najważniejsze determinanty polsko-czeskiej współpracy transgranicznej. Analiza podmiotów transgranicznych została przeprowadzona na płaszczyznach: genetycznej, strukturalnej i funkcjonalnej. Omówiono programy UE wspierające pogranicze polsko-czeskie, w tym ich strukturę podmiotową i przedmiotową. Dzięki przeprowadzonym badaniom możliwe było przedstawienie wniosków dotyczących wyzwań stojących przed polsko-czeskimi podmiotami transgranicznymi po $2020 \mathrm{r}$.

W tekście krytycznej weryfikacji poddane zostały następujące hipotezy badawcze:

- polsko-czeska współpraca transgraniczna uwarunkowana była szeregiem determinantów, które przyczyniły się do powstania i rozwoju euroregionów i europejskich ugrupowań współpracy terytorialnej (EUWT);

- badane podmioty transgraniczne nie ograniczyły suwerenności Polski i Czech, ich działalność pozwoliła na budowę dobrych relacji między obydwoma państwami.

- polsko-czeskie podmioty transgraniczne służyły szeroko rozumianej współpracy społeczności lokalnych i regionalnych, i tym samym przyczyniły się do rozwoju lokalnego i pośrednio regionalnego.

Przy realizacji podjętego problemu badawczego wykorzystano kilka metod i technik badawczych. Metoda instytucjonalno-prawna posłużyła do analizy międzynarodowych i krajowych podstaw normatywnych współpracy transgranicznej oraz charakterystyki aspektu organizacyjnego wybranych euroregionów. Przy porównywaniu genezy, struktur i działalności poszczególnych euroregionów pogranicza zastosowana została metoda porównawcza. W każdym z elementów badań zastosowana została analiza zawartości dokumentów.

\section{Miejsce pogranicza polsko-czeskiego $\mathrm{w}$ literaturze przedmiotu}

W Polsce problematyka zewnętrznej współpracy samorządów terytorialnych pojawiała się w literaturze dopiero w latach 90. XX w., czyli z opóźnieniem w stosunku do Europy Zachodniej. Problematyka transgraniczna miała od początku charakter interdyscyplinarny i zajmowali się nią przedstawiciele wielu dyscyplin naukowych: nauk politycznych, socjologii, geografii, ekonomii, prawa.

Problematyka pogranicza polsko-czeskiego doczekała się stosunkowo bogatej literatury. K. Heffner $(1996,1998)$ podjął się analizy aspektu demograficzno-osadniczego badanego pogranicza. O euroregionach południowego pogranicza, w tym polsko-czeskich, w wymiarze politologicznym pisała S. Sanetra-Półgrabi (2015). W publikacjach S. Dołzbłasz $(2016,2017)$ oraz S. Dołzbłasz i A. Raczyk (2010) poddano analizie sieci powiązań transgranicznych $w$ ramach realizowanych w Polsce programów operacyjnych. Ciekawą pracę analityczną dotyczącą współpracy polsko-czeskich samorządów terytorialnych wraz z rekomendacjami przygotowała A. Skorupska (2014). Wymiar gospodarczy polsko-cze- 
skich relacji transgranicznych omówili m.in. H. Böhm i W. Opioła (2019), J. Kurowska-Pysz (2016). O społeczeństwie pogranicza polsko-czeskiego w wymiarze socjologicznym i kulturowym pisali m.in. A. Śliz i M.S. Szczepański (2016), M. Dębicki (2010) i H. Rusek (2001). Natomiast szczegółowej analizy turystyki na obszarach przygranicznych Polski podjęli się m.in.: M. Więckowski (2010) oraz J. Potocki (2009). Obydwaj autorzy stwierdzili, że turystyka stanowi znaczący element współpracy polsko-czeskiej, który ma duży potencjał do dalszego rozwoju.

Istotne były też badania dotyczące aspektów środowiska przyrodniczego w tym współpracy w zakresie prawnej ochrony przyrody, zarówno na tle innych granic jak też w ujęciu lokalnym i regionalnym. Warte podkreślenia jest, że autorzy stwierdzają, iż terytorialne jednostki obszarów chronionych, zwłaszcza parków narodowych tworzą istotne platformy współpracy i współdecydują o rozwoju instytucjonalnym pogranicza (Ładysz, 2006; Dołzbłasz, 2013; Więckowski, 2013, 2018). Podkreślano również, że spektakularnym sukcesem polsko-czeskiej współpracy jest utworzenie w 2009 r., pierwszego na świecie transgranicznego Parku Ciemnego Nieba (Kałuski, 2017, s. 184). Ukazało się również kilka publikacji wydanych przez poszczególne euroregiony, ale miały one z reguły charakter promocyjny. Zauważalny jest brak opracowania, które by całościowo analizowało aspekt instytucjonalny polsko-czeskiej współpracy transgranicznej.

Hipotetycznie współpraca transgraniczna na polsko-czeskim pograniczu mogłaby być siłą napędową pozwalającą przezwyciężyć marginalizację (Vaishar i inni, 2013). Jeřábek (2002) ocenił ogólną sytuację w terenie, a J. Ptáček i T. Mintálová (2012) zdefiniowali 5 etapów rozwoju współpracy w ramach czesko-polskiej granicy:

1. 1989-1992 dzika (spontaniczna) współpraca;

2. 1993-1996 ustanowienie regionów przygranicznych (euroregiony);

3. 1997-2004 wykorzystanie funduszy Phare CBC na współpracę;

4. okres przejściowy 2004-2007 między przystąpieniem obu krajów do UE i do strefy Schengen;

5. 2007 r. i późniejsza poprawa warunków współpracy w strefie Schengen.

Zaproponowana w niniejszym artykule analiza instytucjonalna polsko-czeskiego pogranicza wydaje się być jednym z kluczowych tematów dotyczących granic w Europie Środkowej zwłaszcza dotyczących zarządzania, planowania i administrowania pograniczami (Kolosov i Więckowski, 2018).

\section{Pojęcie i istota współpracy transgranicznej}

Współpraca transgraniczna jest niewątpliwie złożonym procesem międzynarodowym. Współpracę transgraniczną można zdefiniować jako „szczególną formę współpracy międzynarodowej, eksponującą dwie podstawowe cechy: sąsiedzkość kontaktów (dotyczy ona tylko bezpośrednio do siebie przylegających obszarów przygranicznych) i regionalny lub lokalny poziom współpracy" (Borys, 1999, s. 69). Podobne rozumienie współpracy transgranicznej można znaleźć w Praktycznym podręczniku współpracy transgranicznej, gdzie za ten rodzaj współpracy uważa się „bezpośrednią sąsiedzką współpracę władz regionalnych i lokalnych wzdłuż granicy we wszystkich dziedzinach życia przy udziale wszystkich zainteresowanych stron" (Praktyczny przewodnik..., 2000, s. 12). Bardziej precyzyjna jest terminologia zawarta w ogólnoeuropejskich regulacjach prawnych, gdzie szczególny 
nacisk położony został na aspekt współpracy i działania. Zgodnie z definicją przyjętą przez Europejską konwencję ramową o współpracy transgranicznej między wspólnotami i władzami terytorialnymi (tzw. konwencję madrycką), za współpracę transgraniczną uznaje się „każde wspólnie podjęte działanie mające na celu umacnianie i dalszy rozwój sąsiedzkich kontaktów między wspólnotami i władzami terytorialnymi dwóch lub większej liczby umawiających się stron, jak również zawarcie porozumień i przyjęcie uzgodnień koniecznych do realizacji takich zamierzeń" (Jóskowiak, 2008, s. 39). Współpraca transgraniczna została podobnie określona w Europejskiej karcie regionów granicznych i transgranicznych, gdzie za ten rodzaj współpracy uważa się „współpracę sąsiedzką przylegających do siebie regionów granicznych lub współpracę zagraniczną władz szczebla regionalnego i lokalnego, organizacji lub instytucji reprezentujących obszary graniczne" (Kawałko, 2011, s. 35).

Podejmując próbę teoretycznej syntezy tego zjawiska, uzasadnionym wydaje się przedstawienie także definicji negatywnej, która precyzyjnie określi, czym ten rodzaj działania międzynarodowego na pewno nie jest. Według takiego podejścia współpraca transgraniczna nie jest: polityką zagraniczną państwa czy społeczności regionalnej i lokalnej; środkiem, za pomocą którego samorząd terytorialny mógłby uzyskać kompetencje szersze niż przyznane w prawie wewnętrznym; nową formą władz lokalnych lub regionalnych o charakterze ponadnarodowym; zagrożeniem dla integralności terytorialnej i ekonomicznej państwa (Albanese, 1996; Jóskowiak, 2004).

Najwyższym stopniem instytucjonalizacji struktur współdziałania transgranicznego charakteryzują się euroregiony. Współpraca transgraniczna nabiera cech współpracy euroregionalnej wraz z wprowadzeniem stałych, instytucjonalnych form współdziałania takich jak: stowarzyszenia, rady, sekretariaty, grupy robocze, a także nawiązaniem licznych powiązań z międzynarodowymi i krajowymi instytucjami koordynującymi współpracę transgraniczną (Małecka, 2007). Pojęcie euroregionu, podobnie jak pojęcie współpracy transgranicznej, nie należy do precyzyjnych i jest trudne do zdefiniowania. W literaturze przedmiotu występuje wiele definicji terminu euroregion. W Encyklopedii politologii euroregion rozumiany jest jako „obszar przekraczający co najmniej jedną granicę państwową i stanowiący sumę co najmniej dwu przestrzeni społeczno-gospodarczych o policentrycznym sposobie organizacji" (Florczak i Łoś-Nowak, 1997, s. 104). Podobne rozumienie pojęcia euroregionu znajduje się w Praktycznym podręczniku współpracy transgranicznej, według którego euroregion stanowi „platformę strategicznej i długofalowej współpracy władz regionalnych i lokalnych po obu stronach granicy państwowej, we wszystkich dziedzinach życia codziennego, niekiedy posiadającą zgromadzenie parlamentarne" (Praktyczny przewodnik..., 2000, s. 8). Negatywną definicję euroregionu prezentuje B. Słowińska (2005), według której euroregion na pewno nie jest: organizacją wspierania gospodarki (instytucją otoczenia biznesu), instytucją stworzoną na żądanie Unii Europejskiej (UE) lub jej ekspozyturą, urzędem ze specjalnymi zadaniami, narzędziem, przy pomocy którego można w krótkim czasie zlikwidować bariery strukturalne w regionie.

W literaturze przedmiotu istnieje zróżnicowana typologia euroregionów. Na uwagę zasługuje propozycja teoretyczna E. Medeirosa (2011). Na podstawie szeregu kryteriów (rodzaju podmiotów, artykulacji terytorialnej, czasu współpracy, intensywności współpracy, rodzaju partnerstwa, strategii transgranicznej i efektu bariery) rozróżnił on cztery modele współpracy transgranicznej w Europie: (1) model „prawdziwej” współpracy transgranicznej, (2) model strukturalnej współpracy transgranicznej, (3) model „wzrastającej” współpracy transgranicznej i (4) model „pseudo” współpracy transgranicznej. Wymienione modele 
sąjednocześniefazamiintegracjieuroregionalnej. Pierwszymodel zakładasilnątransgraniczną współpracę instytucjonalną koordynowaną przez podmioty z szerokim kompetencjami i osobowością prawną. Jest to model idealny, który może zaistnieć tylko w regionach o długich tradycjach współpracy, silnej tożsamości kulturowej i odrębności geograficznej. Model strukturalny jest bardzo podobny do poprzedniego. Zakłada jednak wciąż istnienie silnych barier administracyjnych i instytucjonalnych. Słabo rozwinięta jest w nim również transgraniczna polityka społeczna. Także w tym przypadku nie wyklucza się możliwości istnienia euroregionów. Trzeci model charakteryzuje brak tradycji współpracy transgranicznej oraz niski poziom jej instytucjonalizacji. Ostatni model jest całkowitym przeciwieństwem pierwszego i zakłada słabość procesów transgranicznych oraz istnienie silnego efektu bariery we wszystkich wymiarach współpracy. Euroregiony działające w Polsce i Czechach odpowiadają modelowi strukturalnemu. Listę działających w Polsce euroregionów prezentuje tabela 1.

Nową, bardziej zinstytucjonalizowaną formę współpracy transgranicznej, stanowi europejskie ugrupowanie współpracy terytorialnej (EUWT). Jest to instytucja wprowadzona przez prawo wspólnotowe, umożliwiająca tworzenie sformalizowanych grup współpracy przez podmioty publiczne z różnych państw członkowskich. Stanowi ona odpowiedź na problemy wynikające ze zróżnicowania systemów prawnych w poszczególnych państwach, z jakimi borykały się wcześniej euroregiony. Celem tworzenia EUWT jest zmniejszenie wiążących się z tym trudności i większa harmonizacja współpracy terytorialnej. Ponadto, dzięki zastosowaniu nowego instrumentu prawnego, w dłuższej perspektywie

Tabela 1. Chronologia powstawania euroregionów w Polsce A chronology of the emergence of Euroregions with Polish participation

\begin{tabular}{|c|c|c|}
\hline $\begin{array}{l}\text { Nazwa euroregionu } \\
\text { Name of Euroregion }\end{array}$ & $\begin{array}{c}\text { Data utworzenia } \\
\text { Date of establishment }\end{array}$ & $\begin{array}{c}\text { Państwa członkowskie } \\
\text { Member States }\end{array}$ \\
\hline Nysa & 21 grudnia $1991 \mathrm{r}$. & Polska, Czechy, Niemcy \\
\hline Karpacki & 14 lutego 1993 r. & Polska, Słowacja, Ukraina, Węgry, Rumunia \\
\hline Sprewa-Nysa-Bóbr & 21 września 1993 r. & Polska, Niemcy \\
\hline Pro Europa Viadrina & 21 grudnia 1993 r. & Polska, Niemcy \\
\hline Tatry & 26 sierpnia $1994 \mathrm{r}$. & Polska, Słowacja \\
\hline Bug & 29 września 1995 r. & Polska, Białoruś, Ukraina \\
\hline Pomerania & 15 grudnia $1995 r$. & Polska, Niemcy, Szwecja \\
\hline Glacensis & 5 grudnia 1996 r. & Polska, Czechy \\
\hline Niemen & 6 czerwca 1997 r. & Polska, Białoruś, Litwa \\
\hline Pradziad & 2 lipca 1997 r. & Polska, Czechy \\
\hline Bałtyk & 22 lutego $1998 \mathrm{r}$. & Polska, Litwa, Łotwa, Rosja, Dania, Szwecja \\
\hline Śląsk Cieszyński & 22 kwietnia 1998 r. & Polska, Czechy \\
\hline Silesia & 20 września 1998 r. & Polska, Czechy \\
\hline Beskidy & 9 czerwca 2000 r. & Polska, Słowacja, Czechy \\
\hline Puszcza Białowieska & 25 maja 2002 r. & Polska, Białoruś \\
\hline Łyna-Ława & 4 września 2003 r. & Polska, Rosja \\
\hline
\end{tabular}

Opracowanie własne, podobnie pozostała tabela / Autohr's own elaboration, like remaining table. 
możliwa ma być większa spójność społeczno-gospodarcza UE, o której mowa w artykule 159 Traktatu ustanawiającego Wspólnotę Europejską (WE) (Dołzbłasz i Raczyk, 2010).

Cechą wyróżniającą EUWT spośród innych instytucji wspierających współpracę terytorialną, jest osobowość prawna, a w konsekwencji pełna zdolność do czynności prawnych w rozumieniu poszczególnych systemów prawa krajowego. Oznacza to, że EUWT mogą nabywać i zbywać ruchomości i nieruchomości, zatrudniać pracowników, występować jako strona w postępowaniu sądowym. EUWT uzyskuje osobowość prawną z chwilą rejestracji lub publikacji statutu zgodnie z prawem krajowym państwa członkowskiego, w którym znajduje się siedziba statutowa nowego ugrupowania (Dumała, 2009). Jego funkcjonowanie jest finansowane przez instytucje powołujące, a koszt założenia i prowadzenia jego bieżącej działalności pokrywany jest ze środków własnych, przede wszystkim ze składek członkowskich. Ponadto, EUWT może ubiegać się o środki tak jak inni beneficjenci realizujący projekty ze środków UE (Bussmann, 2008).

Dotychczasowe doświadczenia wskazują na istnienie wielu barier, które ograniczają pełne wykorzystanie nowego instrumentu prawnego. Poważne trudności występują zarówno podczas rejestracji, jak i w procesie zarządzania EUWT. Państwa członkowskie nie zdecydowały się bowiem na przeniesienie swoich uprawnień dotyczących zarządzania funduszami UE na EUWT. Ponadto sytuacja finansowa EUWT jest bardzo zróżnicowana. Tylko kilka ugrupowań ma budżet liczący ponad $1 \mathrm{mln}$ euro. Są to głównie euroregiony mające wieloletnie doświadczenie we współpracy transgranicznej. W najgorszej sytuacji są małe ugrupowania znajdujące się w biedniejszych węgierskich regionach przygranicznych. Budżet wszystkich EUWT (ok. 60 mln euro) można porównać z budżetem przeciętnego polskiego powiatu. Ugrupowaniom często brakuje środków niezbędnych do wykonania ambitnych zadań określonych w dokumentach założycielskich (Studzieniecki i Mazurek, 2018). Chronologię tworzenia ugrupowań w Polsce prezentuje tabela 2.

Reasumując rozważania teoretyczne: współpraca transgraniczna nie stanowi czynnika zagrażającego integralności terytorialnej państwa. Jej głównym zadaniem jest znoszenie barier między obszarami położonymi po obu stronach granicy. Celami szczegółowymi współpracy transgranicznej są m.in.: przezwyciężanie stereotypów i uprzedzeń między lokalnymi społecznościami, usuwanie barier politycznych i administracyjnych, rozwój infrastruktury czy poprawa jakości życia. Podobnie euroregiony nie stanowią żadnych nowych organizmów ponadpaństwowych. Ramy współpracy euroregionalnej są określane przez państwa i muszą być zgodne z przyjętymi przez nie międzynarodowymi zobowiązaniami i standardami. Dzięki istnieniu euroregionów granice mają się stawać bardziej otwarte dla ludzi, idei, towarów i usług. Ze względu na swój międzynarodowy i integracyjny charakter korzystają z politycznego wsparcia Rady Europy i UE. Dużym wyzwaniem dla współpracy

Tabela 2. Chronologia powstawania EUWT w Polsce

A chronology of the emergence of EGTCS with Polish participation

\begin{tabular}{|l|l|l|}
\hline \multicolumn{1}{|c|}{$\begin{array}{c}\text { Nazwa ugrupowania } \\
\text { Name of Grouping }\end{array}$} & \multicolumn{1}{|c|}{$\begin{array}{c}\text { Data utworzenia } \\
\text { Date of establishment }\end{array}$} & \multicolumn{1}{c|}{$\begin{array}{c}\text { Państwa członkowskie } \\
\text { Member States }\end{array}$} \\
\hline Tritia & 25 lutego 2013 r. & Polska, Czechy, Słowacja \\
Tatry & 20 września 2013 r. & Polska, Słowacja \\
Środkowoeuropejski Korytarz Transportowy & 24 marca 2014 r. & Polska, Chorwacja, Węgry, Szwecja \\
Novum & 16 grudnia 2015 r. & Polska, Czechy \\
\hline
\end{tabular}


transgranicznej jest również nowa inicjatywa UE, czyli europejskie ugrupowanie współpracy terytorialnej.

\section{Uwarunkowania polsko-czeskiej współpracy transgranicznej}

Obecnie granica polsko-czeska ma długość 761,8 km i stanowi około 22,7\% całkowitej długości granic Polski. Po stronie polskiej granica z Czechami przebiega przez obszar trzech województw: dolnośląskiego, opolskiego i śląskiego, po czeskiej zaś obejmuje pięć krajów: liberecki, kralowohradecki, pardubicki, ołomuniecki i morawsko-śląski. Na pograniczu polsko-czeskim można wyróżnić następujące uwarunkowania współpracy transgranicznej: historyczne, przyrodnicze i społeczno-gospodarcze. Biorąc pod uwagę uwarunkowania historyczne, polsko-czeska (wcześniej polsko-czechosłowacka) współpraca transgraniczna przechodziła w XX w. kilka etapów rozwoju. W okresie międzywojennym ze względu na liczne konflikty, głównie o charakterze etnicznym i granicznym, istotnym elementem było podpisanie konwencji praskiej w 1925 r., regulującej te kwestie i umożliwiającej rozwój stosunków gospodarczych, kulturalnych i naukowych. Na podstawie podpisanej wówczas konwencji turystycznej wprowadzono swobodny ruch turystyczny na obszarze pogranicza Polski i Czechosłowacji. Po II wojnie światowej pozytywne zmiany przyniosło ponowne wprowadzenie konwencji turystycznej i umowy o małym ruchu granicznym w latach 50. XX w. Zliberalizowane zostały wówczas przepisy o ruchu transgranicznym, z czego korzystali głównie turyści i ludność pogranicza. Lata 80. XX w. przyniosły ponowną izolację polityczną i znaczne ograniczenie powiązań. Przełomem były, podobnie jak w całej Europie Środkowej, lata 90. XX w., kiedy to nastąpiła reaktywacja samorządów terytorialnych w obu państwach i rozwój współpracy transgranicznej we współczesnej formie (Dołzbłasz i Raczyk, 2010).

Ważnym czynnikiem determinującym charakter współpracy na pograniczu polsko-czeskim są uwarunkowania przyrodnicze. Wynikają one z usytuowania w obszarze atrakcyjnym turystycznie (m.in. turystyka górska, liczne miejscowości uzdrowiskowe, bardzo duża liczba obiektów zabytkowych) i cennym przyrodniczo (m.in. liczne parki narodowe i krajobrazowe). Efektem tego są większe możliwości integracji na obszarze pogranicza polsko-czeskiego (Potocki, 2009). Jednocześnie może się to wiązać z wytworzeniem i utrwaleniem „monokultury współpracy” i zdominowanie jej przez działania związane z turystyką. Górski charakter pogranicza stanowi także barierę komunikacyjną. W tym zakresie ważna jest liczba połączeń transportowych. Do 2007 r. na wspólnym pograniczu istniało ponad 100 przejść granicznych - 107 drogowych (w tym 37 dla małego ruchu granicznego), 22 na szlakach turystycznych oraz 9 przejść kolejowych. Po akcesji Polski i Czech do strefy Schengen wszystkie przejścia graniczne na wspólnej granicy zostały zlikwidowane. Zachowana została infrastruktura tylko tych przejść, których utrzymanie jest niezbędne do przywrócenia kontroli granicznej w szczególnych przypadkach. W kontekście połączeń transportowych szczególnie odczuwalna może być bariera ekologiczna związana z koncentracją obszarów chronionych przylegających do granicy państwowej, co utrudnia budowę nowych szlaków transportowych, a w konsekwencji przepływ ludzi. Może to jednak stanowić podstawę rozwoju współpracy transgranicznej w zakresie ochrony środowiska (Dołzbłasz i Raczyk, 2010; Dołzbłasz, 2013; Więckowski, 2018). 
Zgodnie z prawem międzynarodowym stosunki dwustronne pomiędzy Polską i Czechami regulują następujące traktaty i umowy bilateralne: Układ między Rzeczpospolitą Polską a Czeską i Słowacką Republiką Federacyjną o dobrym sąsiedztwie, solidarności i przyjaznej współpracy z 6 października 1991 r. (dotyczący Republiki Czeskiej z racji ciągłości politycznej); Porozumienie między Rządem Rzeczpospolitej Polskiej i Rządem Republiki Czeskiej o współpracy transgranicznej z 18 sierpnia 1994 r.; Umowa między Rzeczpospolitą Polską a Republiką Czeską o małym ruchu granicznym, sporządzona w Pradze 17 stycznia 1995 r., ratyfikowana przez Polskę w lutym 1996 r. (Kukułka, 1998). Głównym dokumentem z racji członkostwa Polski i Czech od 2004 r. w UE są traktaty europejskie (obecnie Traktat z Lizbony) (Barcz i inni, 2012). Do tego należy zaliczyć liczne dokumenty niższej rangi m.in. umowy pomiędzy strukturami samorządowymi na różnych szczeblach, organizacjami gospodarczymi i organizacjami pozarządowymi. W stosunkach dwustronnych zasadniczą rolę we współpracy polsko-czeskiej odgrywa powołana w 1994 r. Komisja Rządowa do spraw Współpracy Transgranicznej, która w czasie swoich posiedzeń inspiruje i wspiera inicjatywy transgraniczne. Ważnym czynnikiem pogłębiania współpracy na pograniczu polsko-czeskim były inicjatywy na rzecz tworzenia regionalnych dokumentów współpracy transgranicznej w postaci różnych form koncepcji rozwoju przestrzeni pogranicza polsko-czeskiego. W nowych warunkach ustrojowych w Polsce po 1989 r. i po powstaniu w 1993 r. Republiki Czeskiej do najważniejszych dokumentów rozwoju pogranicza polsko-czeskiego zaliczyć należy: Koncepcję rozwoju pogranicza polsko-czeskiego (1996 r.); Studium rozwoju pogranicza polsko-czeskiego. Synteza dokumentów krajowych (2006 r.); Program operacyjny współpracy transgranicznej Republika Czeska-Rzeczpospolita Polska 2007-2013, wersja 2 (2010 r.); Strategię zintegrowanej współpracy czesko-polskiego pogranicza (2014 r.). Zauważalna jest dobrze rozwinięta infrastruktura prawna dotycząca polsko-czeskiej współpracy transgranicznej (Adamczuk, 2015).

Mieszkańców pogranicza łączy bliskość językowa, z tego względu bariera kulturowa na granicy południowej jest relatywnie mniejsza niż np. na granicy zachodniej. Istotny dla rozwoju kontaktów transgranicznych jest również brak silnych negatywnych stereotypów i uprzedzeń. Na czeskim Zaolziu zamieszkuje mniejszość polska. Organizacje i stowarzyszenia polskie działające w Czechach (także poza obszarem Zaolzia) skupione są w Kongresie Polaków w Republice Czeskiej, mającym siedzibę w Czeskim Cieszynie. W kontaktach z urzędami można posługiwać się językiem polskim. W miejscowościach na Zaolziu, w których co najmniej 10\% mieszkańców stanowią Polacy, wprowadzano dwujęzyczne tablice wjazdowe i informacyjne, a także na siedzibach urzędów. Dwujęzyczne nazwy stacji pojawiają się również na niektórych dworcach. W ostrawskim studiu Telewizji Czeskiej nadawane są kilkuminutowe wiadomości w języku polskim. Według danych na rok szkolny 2015/2016, Polacy posiadają 33 przedszkola, do których uczęszcza 860 dzieci, 25 szkół podstawowych z 1822 uczniami, jedną szkołę średnią - gimnazjum im. Juliusza Słowackiego w Czeskim Cieszynie, do której uczęszcza 317 uczniów. W 3 czeskich szkołach średnich dla polskiej młodzieży zapewnione są zajęcia z języka polskiego, a w razie dostatecznej liczby uczniów możliwe jest utworzenie klasy z polskim językiem wykładowym. Obecnie takie klasy istnieją w Akademii Handlowej w Czeskim Cieszynie (uczęszcza do nich 47 uczniów). W spisie ludności z 2011 r. narodowość polską zadeklarowało 26551 osób, a narodowość podwójną polską i czeską 2151 osób (Gąsior, 2016). Po stronie polskiej żyją również nieliczni Czesi w dość znacznym rozproszeniu, jak na przykład mniejszość czeska zamieszkująca w Zelowie w pobliżu Bełchatowa (Śliz i Szczepański, 2016). 
W polskiej części pogranicza polsko-czeskiego następują zmiany ludnościowe. Zaobserwować można wyraźny spadek liczby ludności tego obszaru. Jednocześnie należy podkreślić, że po polskiej stronie pogranicza gęstość zaludnienia jest znacznie wyższa niż średnia kraju i wynosi 157 osób na km², co wskazuje na znaczną koncentrację ludności i zarazem wciąż znaczący potencjał ludnościowy tego obszaru. Na całym pograniczu występują ośrodki przemysłowe, tereny wiejskie, ośrodki usługowe oraz miejska struktura gospodarcza, tak więc pod tym względem ciężko jest określić dominujący sektor gospodarki. Przedsiębiorstwa funkcjonujące w regionie obejmują m.in. zakłady przemysłu ciężkiego i branży energetycznej oraz produkcję tkanin, odzieży, przemysł maszynowy, szklarski, ceramiczny i spożywczy. Coraz ważniejszą rolę w regionie odgrywa turystyka. Występują również obszary kryzysu, takie jak Wałbrzych. Reasumując: pogranicze stanowi przykład obszaru przemysłowego i atrakcyjnego turystycznie o relatywnie niskim poziomie dysproporcji społeczno-gospodarczym z zauważalnym spadkiem liczby mieszkańców (Róg, 2013).

\section{Programy UE na pograniczu polsko-czeskim}

W okresie przedakcesyjnym współpraca transgraniczna wspomagana była programem Phare. Sam program utworzony został w 1989 r. w celu wsparcia przemian gospodarczych i ustrojowych w Polsce i na Węgrzech. Dla obszarów przygranicznych istotnym momentem był 1994 r., w którym to powstał podprogram Phare CBC. Zasadniczym celem tego programu było promowanie współpracy regionów przygranicznych UE z państwami Europy Środkowo-Wschodniej, co miało stanowić wstęp do procesów integracji. Szczególną rolę w zarządzaniu Funduszem Małych Projektów (FMP) odegrały euroregiony. Realizowane były małe projekty o wartości do 50 tys. euro, oraz tzw. średnie do 300 tys. euro. Zasadniczym celem ich realizacji była promocja współpracy regionów przygranicznych, która miała przełamać specyficzne problemy tych obszarów z uwzględnieniem ochrony środowiska. Polska uzyskała w latach 1994-2003 na Phare CBC łączną kwotę 537 mln euro, co stanowiło $20 \%$ całości środków programu Phare w Polsce. W ramach FMP wartość zrealizowanych projektów wyniosła $34 \mathrm{mln}$ euro, stanowiących 5\% całości alokacji programu. Na granicę południową przypadało odpowiednio $3 \mathrm{mln}$ euro w latach 1994-1999 i $36 \mathrm{mln}$ euro na lata 2000-2003. Ostatnim rokiem funkcjonowania programu Phare CBC w Polsce był 2003 r. (Dołzbłasz i Raczyk, 2010).

W wyniku akcesji Polski i Czech do UE współpraca transgraniczna została objęta programem Interreg. W latach 2004-2006 w ramach Interreg III dysponowano kwotą 4875 mln złotych, które realizowane były w trzech komponentach: (a) lokalna i regionalna współpraca transgraniczna; (b) współpraca międzynarodowa władz regionalnych i krajowych dużych regionów europejskich, mająca na celu zrównoważony i skoordynowany rozwój przestrzenny; (c) współpraca międzyregionalna w skali europejskiej, obejmująca m.in. wymianę informacji i doświadczeń dotyczących rozwoju regionalnego oraz polityk i technik kohezyjnych (Dołzbłasz i Raczyk, 2010; Miszczuk, 2013). Na pogranicze polsko-czeskie przypadło $18 \mathrm{mln}$ euro (10\% puli krajowej). Wymogiem programu w latach 2000-2006 był obowiązek realizacji priorytetów współpracy z określonej listy. Katalog ten obejmował m.in. następujące cele: promocja rozwoju obszarów miejskich i wiejskich; rozwijanie przedsiębiorczości, turystyki, gospodarki lokalnej oraz inicjatyw związanych 
z zatrudnieniem; integracja rynku pracy; współpraca w zakresie badań, oświaty, kultury, ochrony zdrowia i ludności; ochrona środowiska, efektywność energetyczna i odnawialne źródła energii; infrastruktura o znaczeniu przygranicznym. Wymaganą cechą projektów był również weryfikowalny efekt transgraniczny, rozumiany jako rezultat wspólnych skoordynowanych działań, mający odczuwalny wpływ po obu stronach granicy (Klimczak i inni, 2010). Analiza projektów z południowego pogranicza pokazała dominację przedsięwzięć z zakresu turystyki, w tym głównie wspólnych usług dla przemysłu turystycznego. Na uwagę zasłużył również relatywnie wysoki udział zaawansowanych naukowo projektów badawczych prowadzonych przez uniwersytety i instytucje badawcze. W strukturze podmiotowej zdecydowanie dominowały jednostki samorządu terytorialnego (55\%), tylko 6\% stanowiły stowarzyszenia, a około $9 \%$ szkoły wyższe i inne instytucje naukowe. Stosunkowo niski był odsetek projektów instytucji kultury. Biorąc pod uwagę miejsce realizacji projektów widoczna była zdecydowana dominacja gmin miejskich (42\%). Na podkreślenie zasłużyła duża aktywność beneficjentów z Opola. Zaledwie 21\% projektów realizowały gminy wiejskie. Istotną rolę w rozmieszczeniu przestrzennym współpracy odgrywały obszary atrakcyjne turystycznie (Góry Stołowe, Karkonosze, Beskid Śląski) (Dołzbłasz i Raczyk, 2010).

W okresie programowania 2007-2013 celem polityki regionalnej UE było dążenie do spójności gospodarczej, społecznej i terytorialnej oraz zmniejszenie różnic w poziomie rozwoju. Obejmowały to trzy cele szczegółowe: (a) konwergencję, (b) konkurencyjność regionalną i zatrudnienie i (c) Europejską Współpracę Terytorialną. Celem priorytetowym kolejnego programu był rozwój transgranicznej działalności w wymiarze społecznym, gospodarczym i społecznym na rzecz zrównoważonego rozwoju. Zadanie to było realizowane m.in. poprzez wspieranie przedsiębiorczości, rozwoju małych i średnich przedsiębiorstw, turystyki, kultury, handlu, ochronę zasobów naturalnych, powiązania obszarów miejskich i wiejskich, poprawę sieci transportowych, informacyjnych i komunikacyjnych a także transgranicznych systemów dostawy wody, energii oraz zagospodarowania odpadów, w tym zdolności wspólnego wykorzystania infrastruktury. Polskie pogranicza na EWT 2007-2013 otrzymały 700 mln euro, z czego na program EWT Polska-Czechy przypadło 258,2 mln euro, co było największą sumą w ramach współpracy transgranicznej. Na pograniczu polsko-czeskim realizowano łącznie cztery priorytety: wzmacnianie dostępności komunikacyjnej i ochrona środowiska, poprawa warunków rozwoju przedsiębiorczości i turystyki, wspieranie współpracy społeczności lokalnych oraz pomoc techniczna (Dołzbłasz, 2017; Miszczuk, 2013). Szczegółowa analiza projektów z lat 2007-2013 pokazała, że istotnym wyróżnikiem pogranicza polsko-czeskiego był wysoki udział imprez kulturalnych (ok. 12\% projektów), czemu sprzyjały m.in. liczne walory kulturowe pogranicza, bliskość geograficzna i relatywnie dobra dostępność transportowa, podobieństwo języka oraz wysoki wskaźnik urbanizacji sprzyjający wyższej liczbie potencjalnych uczestników imprez. Relatywnie dużo zrealizowano projektów związanych z infrastrukturą drogową (ok. 11\%) i bezpieczeństwem publicznym (ok. 8\%). Dużo mniej było projektów w zakresie infrastruktury społecznej. Jeśli chodzi o strukturę beneficjentów dominowały jednostki samorządu terytorialnego (ok. 60\%). Po polskiej stronie przeważały samorządy szczebla lokalnego, po czeskiej zaś najwięcej było jednostek szczebla regionalnego (ok. 10\%), co wynikało z braku powiatów w strukturze administracyjnej Czech. Pod względem aktywności trzeciego sektora, korzystniej kształtowała się sytuacja po stronie czeskiej, gdzie ich udział wyniósł ok. 17\%, przy $8 \%$ polskich beneficjentów. Aktywność instytucji nauko- 
wych i kulturalnych wyniosła ok. 6-7,5\%. W rozmieszczeniu przestrzennym beneficjentów zauważalna była koncentracja w pobliżu granicy państwowej (ok. 40\% beneficjentów zlokalizowanych było w pasie granicznym do $10 \mathrm{~km}$ ). Ważnym czynnikiem wpływającym na rozwój współpracy była także lokalizacja beneficjentów na obszarach atrakcyjnych turystycznie (Karkonosze, Góry Izerskie, Beskid Śląski) oraz w większych ośrodkach miejskich z dobrą dostępnością transportową (Ołomuniec, Opole, Hradec Králové, Jelenia Góra) (Dołzbłasz, 2017).

W obecnie realizowanym okresie programowania 2014-2020 również występuje Program Operacyjny Republika Czeska-Polska. Budżet na poziomie $226 \mathrm{mln}$ euro jest ponownie największym spośród wszystkich programów transgranicznych w Polsce. Obszar wsparcia dotyczył części województw: dolnośląskiego i śląskiego oraz województwo opolskie po stronie polskiej oraz pięciu krajów po stronie czeskiej (liberecki, kralowohradecki, ołomuniecki, pardubicki i morawsko-śląski). Ponad połowę budżetu programu przeznaczono na ochronę, wykorzystanie oraz poprawę dostępności transportowej atrakcji kulturowych i przyrodniczych pogranicza polsko-czeskiego. Działania te były uzupełnione przez promocję walorów turystycznych regionu, co pomogło w stworzeniu nowych miejsc pracy. Dodatkowo proces walki z bezrobociem był wspomagany działaniami z zakresu edukacji oraz podnoszenia kwalifikacji i uznawalności dyplomów. W sposób szczególny promowana była także nauka języka sąsiada. Kolejnym ważnym obszarem wsparcia było bezpieczeństwo. Wzmocniono kompatybilność i połączenia systemów reagowania kryzysowego w Polsce i Czechach. Środkami w realizacji tego celu były transgraniczne szkolenia służb ratowniczych i porządkowych oraz zakup sprzętu niezbędnego do wspólnych interwencji. Uzupełnieniem programu było wsparcie współpracy instytucji publicznych, lokalnych społeczności i sektora pozarządowego. Zróżnicowane działania w takich obszarach jak: kultura, bezpieczeństwo, edukacja i planowanie przestrzenne skierowane były do szerokich grup odbiorców. Podjęte działania przyczyniły się do wsparcia społeczeństwa obywatelskiego w regionie (Interreg V-A..., 2016). Podsumowując prezentację programów wsparcia obszarów przygranicznych, należy pamiętać, że nie tylko euroregiony korzystały z tej pomocy. Tym samym nie można utożsamiać wskazanych kwot bezpośrednio z euroregionami. Ostatni program operacyjny Polska-Czechy będzie można ocenić całościowo dopiero po jego zakończeniu.

\section{Euroregiony pogranicza polsko-czeskiego}

Na początku lat 90. XX w. samorządy polskie i czeskie zdecydowały się na instytucjonalizację współpracy poprzez utworzenie euroregionów. Przez wiele lat stanowiły one najbardziej zaawansowaną formę współpracy transgranicznej na pograniczu polsko-czeskim. Pierwszy euroregion, o nazwie Nysa, został utworzony przez polskie samorządy w $1991 \mathrm{r}$. W kolejnych latach powstały na wspólnym pograniczu kolejne euroregiony (tab. 1). Szczególnego rodzaju euroregionami są Nysa i Beskidy, które obejmują również terytoria odpowiednio Niemiec i Słowacji. Największym terytorialnie z nich jest Euroregion Nysa, który obejmuje obszar 8,1 tys. km² (uwzględniając wyłącznie stronę polską i czeską). Biorąc pod uwagę potencjał demograficzny, również przoduje Euroregion Nysa (ok. 1,7 mln ludzi), który tylko nieznacznie wyprzedza Euroregion Beskidy. Najmniejszymi pod względem liczby ludności są polskie części euroregionów Silesia i Śląsk Cieszyński. Średnia liczba ludno- 
ści polsko-czeskich euroregionów wynosi 670-770 tys. osób. Najbardziej zurbanizowana jest polska część Euroregionu Glacensis. W częściach zagranicznych wysokim poziomem urbanizacji wyróżniają się czeskie części wszystkich euroregionów tego pogranicza. Jest to związane z przyznawaniem statusu miasta w Czechach relatywnie małym jednostkom osadniczym. W ruchu migracyjnym ludności w zdecydowanej większości euroregionów odpływ przewyższał nad napływem. Najintensywniej zjawisko to wystąpiło m.in. w polskiej części Euroregionu Pradziad. Wskaźnik udziału bezrobotnych w liczbie ludności w wieku 15-64 lata w polskich częściach euroregionów kształtował się w przedziale od 5,3\% w Euroregionie Beskidy do 15,1\% w Euroregionie Łyna-Ława (Kasperek, 2014; Małecka, 2007).

Zasadniczym celem działalności euroregionalnej jest rozwój społeczno-gospodarczy, stała poprawa warunków życia mieszkańców oraz ułatwianie wzajemnych kontaktów pomiędzy społecznościami wspólnoty (Małecka, 2007). Analiza statutów polsko-czeskich euroregionów wskazuje, że najczęściej realizowane było wsparcie rozwoju oraz przepływu informacji transgranicznych. Nieco mniejszą popularność wykazują zadania z zakresu wspólnego przeciwdziałania skutkom kataklizmów, ochrony środowiska naturalnego oraz współpracy na płaszczyźnie kultury. Ponadto wymienia się zadania z zakresu turystyki, budowy infrastruktury technicznej, współpracy edukacyjnej oraz podejmowania wspólnego planowania przestrzennego. Zakres zadań i celów statutowych ewoluował, na co wskazuje nieco szerszy zakres działań powstałych później euroregionów. Zapewne wpływ na to miała również polityka regionalna UE, której priorytety ulegały kilkukrotnym zmianom (Kasperek, 2014).

Idea powołania Euroregionu Nysa pojawiła się na przełomie 1990 i 1991 r. w kręgach polityków, działaczy gospodarczych i naukowców w Żytawie. W wyniku rozmów i konsultacji 15 maja 1991 r. strony podpisały Deklarację o współpracy - partnerstwa transgranicznego, a 23 maja miała miejsce w Żytawie „Konferencja założycielska trójkąta trzech państw", nad którą patronat przyjęli prezydenci państw członkowskich: Vaclav Havel, Lech Wałęsa i Richard von Weizsacker. Zawarto na niej wstępne porozumienie o powołaniu Euroregionu Trójstyk (z tej nazwy zrezygnowano później, zastępując ją oficjalną nazwą Euroregion Neisse-Nisa-Nysa) i przyjęto memorandum określające dalsze kierunki działania. W dniu 21 grudnia 1991 r. odbyło się w Żytawie pierwsze posiedzenie Rady Euroregionu Nysa, które przyjmuje się za oficjalną datę jego powołania. Aktualnie euroregion pod względem administracyjnym tworzą: po niemieckiej części 2 powiaty: Bautzen i Görlitz; po czeskiej 131 gmin położonych w powiatach Liberec, Jablonec nad Nisou, Semily i Česká Lípa kraju libereckiego, gminy cypla šluknovskiego (Šluknovský výběžek) oraz kraj liberecki; po polskiej 44 gminy oraz powiaty: bolesławiecki, jeleniogórski, kamiennogórski, lubański, Iwówecki, zgorzelecki i złotoryjski (www.euroregion-nysa.eu, 2019).

Kolejnym euroregionem powstałym na granicy polsko-czeskiej był Euroregion Glacensis. Początki instytucjonalizacji współpracy transgranicznej w regionie Sudetów Środkowych i Wschodnich sięgają 1992 r. Po wstępnych rozmowach (w połowie 1991 r.) przedstawicieli społeczności lokalnych, 18 września 1992 r. w Wałbrzychu podpisano przez przedstawicieli 21 gmin z terenu województw wałbrzyskiego i opolskiego oraz przedstawicieli miast i powiatów północno-wschodnich Czech Porozumienie o ponadgranicznej współpracy wzajemnej oraz o utworzeniu Ponadgranicznego Związku Miast i Gmin Czechy-Polska. W Porozumieniu za główny cel współpracy uznano koordynację działań na rzecz rozwoju gospodarczego, kulturalnego i społecznego obszarów przygranicznych rejonu Sudetów Środkowych i Wschodnich oraz wspólne rozwiązywanie występujących 
na tym obszarze problemów ekologicznych. Od 1994 r. w kręgach samorządowych strony czeskiej i polskiej zaczęto rozważać koncepcję utworzenia Euroregionu Glacensis (nazwa wywodzi się ze średniowiecznego łacińskiego określenia Ziemi Kłodzkiej). W dniu 9 lutego 1994 r. powstało Stowarzyszenie Gmin Ziemi Kłodzkiej, a 30 maja 1994 r. Sejmik Samorządowy Gmin Województwa Wałbrzyskiego podjął uchwałę w sprawie wystąpienia do rządu RP o zgodę na utworzenie euroregionu. W dniu 16 stycznia 1996 r. w czeskim Rychnovie nad Kněžnou starostowie czeskich samorządów lokalnych z Nachodu, Rychnova, Šumperka, Usti nad Orlici, Trutnova, Orlicke Zahori, Polic nad Metuji oraz prezydent Hradec Králové złożyli deklarację przystąpienia do tworzącego się Euroregionu Glacensis, podpisując umowę o utworzeniu Regionalnego Stowarzyszenia do Spraw Współpracy Pogranicza Czech, Moraw i Ziemi Kłodzkiej. Sfinalizowanie działań związanych z utworzeniem euroregionu miało miejsce 5 grudnia 1996 r. w Hradec Králové. Między Stowarzyszeniem Gmin Ziemi Kłodzkiej i Regionalnym Stowarzyszeniem do Spraw Współpracy Pogranicza Czech, Moraw i Ziemi Kłodzkiej podpisano umowę o utworzeniu Euroregionu Pogranicza Czech, Moraw i Ziemi Kłodzkiej Euroregion Glacensis. Euroregion obejmuje po stronie polskiej 34 gminy i 2 powiaty z województwa dolnośląskiego. Po stronie czeskiej w skład euroregionu wchodzi 97 gmin. Ponadto członkami są także 4 stowarzyszenia gminne i 3 urzędy wojewódzkie. Siedzibą euroregionu jest Rychnov nad Kněžnou po stronie czeskiej i Kłodzko po stronie polskiej (www.euroregion-glacensis.ng.pl).

Jako trzeci powstał na badanych pograniczu Euroregion Pradziad (nazwa euroregionu pochodzi od najwyższego szczytu gór Jesioników). Ideę zbliżenia i współpracy pomiędzy Polską i Czechami w rejonie Jesioników oraz pierwsze kontakty władze samorządowe obu stron podjęły już w 1990 r. Z inicjatywą pierwszego dużego spotkania wyszły władze Jesenika, organizując 21 czerwca 1991 r. konferencję z udziałem przedstawicieli miast i gmin regionu jesenickiego oraz sąsiadujących miast i gmin województwa opolskiego i wałbrzyskiego. Zwieńczeniem wieloletnich starań władz lokalnych i wojewódzkich oraz wzmocnieniem trwającej już kilka lat współpracy pomiędzy samorządami, szkołami, ośrodkami kultury, klubami sportowymi i innymi organizacjami społecznymi było podpisanie 2 lipca 1997 r. w Jeseníku umowy ramowej o utworzeniu czesko-polskiego Euroregionu. Sygnatariuszami umowy byli przedstawiciele Stowarzyszenia Rozwoju Gmin Dorzecza Osobłogi i Unii Turystycznej Ziemi Nyskiej ze strony polskiej oraz stowarzyszeń miast i gmin czeskich powiatów Bruntal i Jesenik. W euroregionie ze strony polskiej znalazły się początkowo gminy: Biała, Głogówek, Głuchołazy, Korfantów, Krapkowice, Lubrza, Nysa, Prudnik i Strzeleczki. Z czeskiej strony do porozumienia przystąpiło 60 gmin, należących do stowarzyszeń gmin: bruntalskich, jesenickich, osoblażskich, rymarzowskich i vrbenskich m.in. z takimi miastami jak: Bruntal, Jesenik, Javornik, Vidnava, Žulová, Osoblaha, Rýmařov, Vrbno pod Pradziadem, Zlate Hory i Město Albrechtice. Dla usprawnienia działalności polskiej części euroregionu, w dniu 7 stycznia 2000 r. zostało utworzone, posiadające osobowość prawną, Stowarzyszenie Gmin Polskich Euroregionu Pradziad skupiające wówczas 14 gmin. Obecnie obejmuje po stronie polskiej 34 gminy oraz 6 powiatów z województwa opolskiego. Ze strony czeskiej Euroregion Pradziad tworzą gminy z powiatów Jesenik i Bruntal: 72 gminy oraz członek wspierający - kraj ołomuniecki. Euroregion Pradziad zajmuje powierzchnię ok. 7,5 tys. $\mathrm{km}^{2}$ i zamieszkuje go ponad 850 tys. mieszkańców (www.europradziad.pl).

Powstanie Euroregionu Silesia poprzedziła Deklaracja o utworzeniu polsko-czeskiego euroregionu, podpisana 3 listopada 1997 r. w Raciborzu. Istotnym etapem w procesie 
tworzenia euroregionu była również polsko-czesko-niemiecka konferencja „Region Opawa-Racibórz - historia i perspektywy w Unii Europejskiej”, która odbyła się w dniach 12-13 września 1997 r. w Raciborzu i Opawie. Do podpisania umowy o utworzeniu Euroregionu Silesia doszło w dniu 20 września 1998 r. w Opawie. Umowa została podpisana przez przedstawicieli Stowarzyszenia Gmin Dorzecza Górnej Odry i Stowarzyszenia Współpracy Czesko-Polskiej Śląska Opawskiego. Euroregion Silesia obejmuje po stronie polskiej 19 gmin z województwa opolskiego i śląskiego. Gminy te leżą na terenie czterech powiatów (jeden powiat z województwa opolskiego i trzy powiaty z województwa śląskiego). Po stronie czeskiej w skład euroregionu wchodzi 56 gmin z czterech powiatów (www. euroregion-silesia.pl).

Umowa o utworzeniu Euroregionu Śląsk Cieszyński została podpisana 22 kwietnia 1998 r. przez Stowarzyszenie Rozwoju i Współpracy Regionalnej „Olza” ze strony polskiej i Regionální sdružení česko-polské spolupráce Těšínského Slezska ze strony czeskiej. Utworzony euroregion stanowi dobrowolną wspólnotę polskich i czeskich związków gmin i miast Śląska Cieszyńskiego. Jego powołanie było ukoronowaniem wieloletniej współpracy polsko-czeskiej w regionie Śląska Cieszyńskiego. Już na początku lat 90. XX w. nawiązane zostały liczne kontakty między władzami samorządowymi po obu stronach granicy. W marcu 1993 r. podpisano umowę między gminnymi związkami regionalnymi o współpracy przygranicznych regionów Śląska Cieszyńskiego. W marcu 1998 r. powstało Stowarzyszenie Rozwoju i Współpracy Regionalnej „Olza” oraz po stronie czeskiej Regionalne Stowarzyszenie Współpracy Czesko-Polskiej Śląska Cieszyńskiego. Po stronie polskiej obszar euroregionu obejmuje 16 gmin oraz powiat cieszyński z województwa śląskiego, a po stronie czeskiej w skład euroregionu wchodzi około 40 gmin z powiatów Karviná i Frydek-Mistek (www.euregio-teschinensis.eu).

Jako ostatni na badanym pograniczu powstał Euroregion Beskidy, trójstronna polsko-czesko-słowacka inicjatywa zapoczątkowana w Rajczy 9 czerwca 2000 r. Cele statutowe Euroregionu Beskidy obejmują szereg działań zmierzających do pogłębienia współpracy na terenach przygranicznych, obejmujących w szczególności: współpracę gospodarczą, turystykę, kulturę, edukację, ochronę środowiska i gospodarkę leśną, rolnictwo i gospodarkę żywnościową, planowanie przestrzenne i budownictwo, pracę i politykę socjalną, przeciwdziałanie katastrofom, awariom i klęskom żywiołowym oraz zwalczanie ich skutków, ochronę zdrowia i ratownictwo medyczne, komunikację i łączność, kulturę fizyczną i sport. Łącznie Euroregion Beskidy obejmuje powierzchnię około 6343 km², w tym część polska - $3288 \mathrm{~km}^{2}$, słowacka - $2083 \mathrm{~km}^{2}$, a czeska - $972 \mathrm{~km}^{2}$. Obszar ten zamieszkiwany jest przez blisko 1385036 mieszkańców (Polacy - 843 536; Słowacy - 295 500, Czesi - 246 000). W skład Stowarzyszenia „Region Beskidy” wchodzi 38 jednostek leżących na terenie województwa śląskiego i małopolskiego, które posiadają status członków zwyczajnych i są jednostki samorządu terytorialnego. Słowackie Združenie „Región Beskydy” z siedzibą w Żylinie liczy 80 członków, a czeskie Sdružení „Region Beskydy” z siedzibą we Frýdku-Místku ma 63 członków (www.euroregion-beskidy.pl).

Należy także wspomnieć o bezprecedensowym w historii Europy przykładzie likwidacji działającego w latach 2001-2003 polsko-czeskiego Euroregionu Dobrawa. Do głównych powodów jego rozwiązania zaliczono między innymi brak symetrii między obszarami objętymi współpracą, wycofanie się z inicjatywy strony czeskiej, konkurencja ze strony sąsiedniego Euroregionu Glacensis, a także nie zaistnienie euroregionu w świadomości społeczności lokalnej (Bednarski, 2006). 


\section{Europejskie ugrupowanie współpracy terytorialnej}

$\mathrm{Na}$ badanym pograniczu funkcjonują obecnie dwa ugrupowania: Tritia i Novum (w całej Polsce mamy cztery EUWT). Decyzja o utworzeniu EUWT Tritia została podjęta w 2009 r. przez liderów samorządów z kraju morawsko-śląskiego (Czechy), województwa opolskiego i śląskiego (Polska) i kraju żylińskiego (Słowacja). Formalnie ugrupowanie zostało założone 25 lutego 2013 r. decyzją Ministra Spraw Zagranicznych Rzeczypospolitej Polskiej i wpisane do rejestru europejskich ugrupowań współpracy terytorialnej, prowadzonego przez resort spraw zagranicznych. EUWT Tritia ma powierzchnię 34069 km² i jest zamieszkałe przez blisko 8 mln mieszkańców. Siedziba ugrupowania znajduje się w Cieszynie. Na terytorium ugrupowania znajdują się dwa duże miasta: Katowice i Ostrawa. Wspomniane obszary aglomeracji miejskich we współpracy z Opolem i Żyliną łączy intensywna współpraca na poziomie ekonomicznym i społecznym. Usytuowanie EUWT Tritia na osi korytarza transportowego Bałtyk-Adriatyk otwiera nowe możliwości inwestycji i tworzenia więzi międzyregionalnych. Na terenie ugrupowania znajduje się siedem uniwersytetów, wysokorozwinięte szkolnictwo wyższe oraz środowisko sprzyjające innowacyjności i działalności badawczo-rozwojowej. EUWT Tritia została założona w celu usprawnienia i promowania współpracy transgranicznej, ponadnarodowej i międzyregionalnej pomiędzy jej członkami poprzez: ułatwienie codziennego życia mieszkańców polsko-czesko-słowackiego pogranicza, zapewnienie transgranicznej spójności na całym obszarze, realizacji projektów strategicznych w celu wspólnego rozwoju obszaru. Ugrupowania realizuje i włącza się na zasadzie partnerstwa w projekty, które związane są z następującymi obszarami tematycznymi: transport, gospodarka, ruch turystyczny, energetyka oraz kultura, ochrona środowiska, kapitał ludzki, edukacja i współpraca szkół wyższych, szkolenia w tym ścisłej współpracy z uczelniami, współpraca z instytucjami publicznymi, a także realizacja wymiany doświadczeń i staży międzynarodowych. Biorąc pod uwagę strategię Europa 2020 oraz polityki spójności UE w okresie programowym 2014-2020, EUWT ma koncentrować się m.in. na następujących zadaniach: wspieraniu przedsiębiorczości, małych i średnich przedsiębiorstw i handlu transgranicznego, ochronie zasobów naturalnych i dziedzictwa kulturowego, wspieraniu wspólnej ochrony dziedzictwa kulturalnego, poprawie dostępu do usług i sieci transportowych, informacyjnych i komunikacyjnych, promocji współpracy między mieszkańcami i instytucjami na terenach przygranicznych (Lewkowicz, 2013; www.egtctritia.eu).

EUWT Novum jest inicjatywą województwa dolnośląskiego, 4 krajów czeskich: kralowohradeckiego, ołomunieckiego, pardubickiego i libereckiego oraz polskich i czeskich części euroregionów Nysa i Glacensis (pierwotna nazwa ugrupowania miała brzmieć "Nowe Sudety", jednak po niespodziewanym oprotestowaniu jej przez przedstawicieli strony czeskiej zaproponowano nazwę „Novum”) (Adamczuk, 2015). Siedziba statutowa i Sekretariat EUWT mieszczą się w Jeleniej Górze. Ugrupowanie zarejestrowane jest w Polsce i podlega polskiemu prawu. Do jego najważniejszych zadań należeć będzie realizacja wspólnych projektów współfinansowanych ze źródeł zewnętrznych (między innymi w ramach polsko-czeskiego programu współpracy transgranicznej na lata 2014-2020), jak również koordynacja współpracy pomiędzy Dolnym Śląskiem i czeskimi regionami z pogranicza. EUWT utrzymywane jest ze składek członkowskich 9 członków-założycieli tego gremium, ma jednak możliwość pozyskiwania funduszy zewnętrznych na finansowanie własnych działań. Ugrupowanie zostało utworzone w celu intensyfikacji, ułatwiania 
i upowszechniania polsko-czeskiej współpracy transgranicznej na rzecz wzmocnienia spójności ekonomicznej i społecznej obszaru działania. Dla osiągnięcia powyższego celu EUWT powinno m.in.: dbać o wspólne wykorzystywanie zasobów ludzkich w sektorach takich jak turystyka, kultura, edukacja i ochrona zdrowia; wspierać wspólną ochronę zasobów naturalnych i kulturowych; poprawiać dostępność do usług i sieci transportowych, informacyjnych i komunikacyjnych; wspierać przedsiębiorczość, badania, rozwój technologiczny i innowacje; propagować integrację transgranicznych rynków pracy; wspierać powiązania między obszarami miejskimi i wiejskimi (www.euwt-novum.eu).

\section{Podsumowanie i rekomendacje}

Pogranicze polsko-czeskie należy do jednego z lepiej rozwiniętych pod względem instytucjonalnym obszarów przygranicznych Polski. Aktualnie funkcjonuje na nim 6 euroregionów i 2 europejskie ugrupowania współpracy terytorialnej (w całej Polsce na 7 pograniczach funkcjonuje 16 euroregionów i 4 EUWT). W wyniku badań pozytywnie zweryfikowano hipotezy przedstawione na wstępie artykułu. Po pierwsze, udowodniono, że polsko-czeska współpraca transgraniczna oparta była na uwarunkowaniach historycznych, prawnych, przyrodniczych i społeczno-gospodarczych. Istotną rolę integracyjną przed 1990 r. odegrały działania w zakresie ochrony środowiska i turystyki. Natomiast późniejsze zmiany społeczno-polityczne, reaktywacja samorządu terytorialnego i budowa infrastruktury prawnej umożliwiły instytucjonalizację powyższej współpracy. Po drugie, potwierdzono, że badani aktorzy transgraniczni nie ograniczyli suwerenności Polski i Czech. Żadne z państw angażujących się we współpracę euroregionalną nie zrezygnowało z jakiegokolwiek atrybutu suwerenności. Także żaden z analizowanych euroregionów i EUWT nie stał się organizmem ponadpaństwowym, wyjętym spod jurysdykcji tworzących go państw. Dzięki istnieniu powyższych podmiotów omawiane pogranicze stało się bardziej przepuszczalne dla ludzi, idei i towarów. Po trzecie, częściowo pozytywnie zweryfikowano hipotezę, iż funkcjonowanie aktorów transgranicznych stanowiło istotny element integracji lokalnej i regionalnej. Jak dotąd, na tym pograniczu najbardziej aktywnymi aktorami współdziałania transgranicznego były euroregiony (chociaż należy również uwzględnić działalność takich podmiotów jak: parki narodowe, szkoły, uczelnie, itd.). Podstawowym celem ich działalności było kreowanie wspólnej przestrzeni społeczno-gospodarczej służącej rozwojowi regionalnemu i budowaniu dobrobytu społeczeństw zamieszkujących pogranicze. Było to realizowane głównie poprzez samorządy terytorialne realizujące mikroprojekty. Jednocześnie zauważalny był brak istotnych inwestycji infrastrukturalnych w regionie oraz niskie zaangażowanie trzeciego sektora.

Na analizowanym pograniczu istnieje również szereg problemów, przed którymi stoją lokalne społeczności. Występują różnice w strukturze administracyjnej (gminy czeskie są pod względem powierzchni znacznie mniejszymi jednostkami niż polskie i niejednokrotnie obejmują tylko jedną miejscowość i maja duże mniejszy zakres kompetencji), które utrudniają rozwój współpracy transgranicznej. Dużym problemem jest finansowaniem bieżącej działalności euroregionów i EUWT. Aktualnie w Polsce i Czechach nie funkcjonuje rządowy program wspierania nowych struktur transgranicznych działający m.in. na Węgrzech. Mimo rekomendacji Komisji Europejskiej, euroregiony i ugrupowania nie zarządzają zarówno Funduszem Mikroprojektów, jak i programem Polska-Republika Czeska 
2014-2020. EUWT Novum i Tritia potencjalnie mogą zagrażać podmiotowości działających na ich obszarze euroregionów, które często współtworzyły (jak np. euroregionowi Glacensis i Nysa). Może to być spowodowane dublowaniem się celów i kompetencji ugrupowań i euroregionów, rywalizacją o pozyskiwanie konkretnych środków finansowych. Ponadto w Polsce brakuje doświadczeń i dobrych praktyk w prowadzeniu ugrupowań (EUWT Tritia jest pierwszym powstałym w Polsce ugrupowaniem). Pewnym problemem może być decyzja o wyborze siedziby statutowej i przyjęciu systemu prawnego ugrupowania (oba polsko-czeskie EUWT przyjęły polski system prawny).

Działające na pograniczu polsko-czeskim podmioty transgraniczne powinny kontynuować działania lobbingowe na szczeblach lokalnym, regionalnym, krajowym i europejskim dotyczące zarządzania Funduszem Mikroprojektów w kolejnych programie operacyjnym po 2020 r. Ponadto powinny one dywersyfikować w większym stopniu pozyskiwane fundusze zewnętrzne (oprócz środków UE aktorzy transgraniczni powinni aplikować m.in. o fundusze z Międzynarodowego Funduszu Wyszehradzkiego, Norweskiego Mechanizmu Finansowego, Funduszu Inwestycyjnego Inicjatywy Trójmorza). Należy zwiększyć udział organizacji pozarządowych w realizacji projektów transgranicznych. Obecnie beneficjentami są głównie samorządy terytorialne i podległe im instytucje. W tym celu niezbędne jest wprowadzenie systemu zaliczek w projektach transgranicznych, co zwiększyłoby udział organizacji pozarządowych w ich realizacji (np. poprzez utworzenie specjalnego funduszu w ramach budżetów krajowych). Wskazane jest również poszerzeniem listy beneficjentów o małych i średnich przedsiębiorców. Należy rozważyć szerszą realizację projektów edukacyjnych dotyczących m.in. nauczania języków czeskiego i polskiego w szkołach pogranicza, dofinansowania kursów językowych dla różnych grup społecznych zainteresowanych współpracą transgraniczną (np. przedsiębiorców, pracowników samorządowych, nauczycieli), publikacji wspólnych podręczników. Niezbędny jest udział wszystkich podmiotów transgranicznych w dyskusji ze stroną rządową nad założeniami programu Polska-Czechy na lata 2021-2027. Należy pamiętać, że na nowy program mogą być przekazane znacznie mniejsze środki niż obecnie, co na pewno wymusi większą koncentrację tematyczną zadań.

\section{Piśmiennictwo}

Adamczuk F., 2015, Uwarunkowania powstania Europejskiego Ugrupowania Współpracy Terytorialnej NOVUM (EUWT NOVUM) na pograniczu polsko-czeskim, Studia i Prace Wydziału Nauk Ekonomicznych i Zarządzania, 40, 1, s. 103-104.

Albanese F., 1996, Współpraca transgraniczna w ramach Rady Europy, [w:] M. Bałtowski (red.), Regiony, euroregiony, rozwój regionalny, 4, Euroregion Bug, Norbertinum, Lublin, s. 34-35.

Barcz J., Kawecka-Wyrzykowska E., Michałowska-Gorywoda K., 2012, Integracja europejska w świetle Traktatu z Lizbony. Aspekty ekonomiczne, Polskie Wydawnictwo Ekonomiczne, Warszawa, s. $15-27$.

Bednarski R., 2006, Likwidacja Euroregionu Dobrava - ewenementem w skali europejskiej, Wyższa Szkoła Ekonomiczna, 4, s. 115-124.

Böhm H., Opioła W., 2019, Czech-Polish Cross-Border (Non) Cooperation in the Field of the Labor Market: Why Does It Seem to Be Un-De-Bordered? Sustainability, Special Issue Sustainable Cross-Border Cooperation: Common Planning, Policies, Strategies, Methods and Activities, 11. 
Borys T., 1999, Obszary transgraniczne w statystyce regionalnej, Główny Urząd Statystyczny, Warszawa.

Bussmann A., 2008, Europejskie ugrupowanie współpracy terytorialnej (EUWT) - przełom we wspótpracy transgranicznej w Unii Europejskiej? Samorząd Terytorialny, 10, s. 7-15.

Dębicki M., 2010, Stereotypy Czechów wobec Polaków na pograniczu - regionalne zróżnicowanie oraz determinanty stanu rzeczy, Wydawnictwo Uniwersytetu Wrocławskiego, Wrocław.

Dołzbłasz S., 2013, Cross-border co-operation in the euroregions at the Polish-Czech and Polish-Slovak borders, European Countryside, 5, 2, s. 102-114.

Dołzbłasz S., 2016, Sieć współpracy transgranicznej na pograniczu polsko-czeskim, Studia Regionalne i Lokalne, 4.

Dołzbłasz S., 2017, Sieci współpracy transgranicznej na pograniczach Polski, Wydawnictwo Uniwersytetu Wrocławskiego, Wrocław.

Dołzbłasz S., Raczyk A., 2010, Współpraca transgraniczna w Polsce po akcesji do UE, Wolters Kluwer, Warszawa.

Dumała H., 2009, Europejskie Ugrupowania Współpracy Terytorialnej-nowe możliwości dla polsko-niemieckich euroregionów, [w:] J. Jańczak, M. Musiał-Karg (red.), Pogranicze polsko-niemieckie po roku 2004. Nowa jakość sq̨siedztwa, Adam Marszałek, Toruń, s. 61-63.

Florczak A., Łoś-Nowak T., (red.), 1997, Encyklopedia politologii. Stosunki międzynarodowe, 5, Zakamycze, Wrocław.

Gąsior G., 2016, Obecność Polaków na Zaolziu w ujęciu historycznym i współczesnym, Opinie i Ekspertyzy, 251, Kancelaria Senatu, Biuro Analiz i Dokumentacji, Warszawa.

Heffner K., 1996, Regiony przygraniczne. Zmieniajqca się rola granicy - od bariery do katalizatora rozwoju społeczno-gospodarczego, [w:] K. Heffner (red.), Region Opawa-Racibórz. Historia i perspektywy w Unii Europejskiej, Instytut Śląski, Opole, s. 120-140.

Heffner K., 1998, Kluczowe problemy demograficzno-osadnicze obszarów przygranicznych Polska-Czechy, Instytut Śląski, Opole.

Interreg V-A Republika Czeska-Polska, wersja 5, 2016, https://www.ewt.gov.pl/media/15939/CZ_ PL_Program.pdf (15.06.2019).

Jeřábek M., 2002, Cross-border cooperation and development in the Czech borderland, Acta Universitatis Carolinae - Geographica, 37, 1, s. 45-60.

Jóskowiak K., 2004, Współpraca transgraniczna Polski - wybrane zagadnienia teorii i praktyki, Zeszyty Naukowe Wyższej Szkoły Zarządzania i Prawa w Warszawie, 2, s. 174-190.

Jóskowiak K., 2008, Samorzqd terytorialny w procesie integracji europejskiej, Wydawnictwo Uniwersytetu Śląskiego, Katowice.

Kałuski S., 2017, Blizny historii. Geografia granic politycznych współczesnego świata, Wydawnictwo Akademickie Dialog, Warszawa.

Kasperek B., (red.), 2014, Euroregiony pogranicza polsko-czeskiego, Stowarzyszenie Rozwoju i Współpracy Regionalnej Olza, Cieszyn, s. 22-30.

Kawałko B., 2011, Wybrane problemy polsko-ukraińskiej współpracy transgranicznej, Barometr Regionalny, 2, 24, s. 35-60.

Klimczak T. i inni, 2010, Badanie ewaluacyjne ex-post efektów transgranicznej współpracy polskich regionów w okresie 2004-2006, Centrum Rozwoju Społeczno-Gospodarczego, Warszawa, http://www.ewaluacja.gov.pl/media/23133/rrit_086.pdf.

Kolosov V., Więckowski M., 2018, Border changes in Central and Eastern Europe: An introduction, Geographia Polonica, 91, 1, s. 5-16.

Kukułka J., 1998, Traktaty sq̨siedzkie Polski odrodzonej, Ossolineum, Wrocław, s. 87-90. 
Kurowska-Pysz J., 2016, Opportunities for cross-border entrepreneurship development in a cluster model exemplified by the Polish-Czech border region, Sustainability, 8 (3), 230.

Lewkowicz Ł., 2013, Euroregiony na pograniczu polsko-słowackim. Geneza i funkcjonowanie, Wydawnictwo Uniwersytetu Marii Curie-Skłodowskiej, Lublin.

Ładysz J., 2006, Chosen aspects of sustainable development on the Polish, Czech and German borderland, GeoJournal, 67, 1, s. 1-7.

Małecka E., 2007, Euroregiony na granicach Polski 2007, Główny Urząd Statystyczny, Wrocław, s. $15-30$.

Medeiros E., 2011, (Re) defining the Euroregion Concept, European Planning Studies, 19, s. 12-17. Miszczuk A., 2013, Uwarunkowania peryferyjności regionu przygranicznego, Norbertinum, Lublin.

Potocki J., 2009, Funkcje turystyki w kształtowaniu transgranicznego regionu górskiego Sudetów, Wydawnictwo Wrocławskiego Towarzystwa Naukowego, Wrocław.

Praktyczny przewodnik współpracy transgranicznej, 2000, Association of European Border Regions, Gronau, s. 8, 12.

Ptáček J., Mintálová T., 2012, Perception of cross-border cooperation in the Czech and Polish border area on the example of the Jeseník region, Acta Universitatis Palackianae Olomucensis - Geographica, 43, 1, s. 31-49.

Róg J., 2013, Procesy integracyjne na pograniczu polsko-czeskim, Zeszyty Naukowe Politechniki Śląskiej. Seria: Organizacja i Zarządzanie, 65, s. 345-360.

Rusek H., 2001, Pogranicza środkowoeuropejskie - nowe oblicza sq̨siedztwa. Na przykładzie pogranicza polsko-czeskiego, Sprawy Narodowościowe. Seria Nowa, 19.

Sanetra-Półgrabi S., 2015, Funkcjonowanie euroregionów na pograniczu południowym Polski. Studium porównawcze euroregionów: "Śląsk Cieszyński", „Beskidy" $i$ „Tatry", Wydawnictwo Adam Marszałek, Toruń.

Skorupska A., 2014, Współpraca samorządowa na pograniczu polsko-czeskich, Polski Instytut Spraw Międzynarodowych - PISM Policy Paper, 17 (100), s. 1-8.

Słowińska B., 2005, Międzynarodowa współpraca jednostek samorzqdu terytorialnego, [w:] W. Kosiedowski (red.), Samorzqd terytorialny w procesie rozwoju regionalnego i lokalnego, Towarzystwo Naukowe Organizacji i Kierownictwa Dom Organizatora, Toruń, s. 324-339.

Strona internetowa Euroregionu Beskidy, http://www.euroregion-beskidy.pl (15.06.2019).

Strona internetowa Euroregionu Glacensis, http://www.euroregion-glacensis.ng.pl/index. php/pl/ (15.06.2019).

Strona internetowa Euroregionu Nysa, http://www.euroregion-nysa.eu (15.06.2019).

Strona internetowa Euroregionu Pradziad, http://www.europradziad.pl (15.06.2019).

Strona internetowa Euroregionu Silesia, http://www.euroregion-silesia.pl (15.06.2019).

Strona internetowa Euroregionu Śląsk Cieszyński, http://www.euregio-teschinensis.eu/ euroregion-slask-cieszynski/(15.06.2019).

Strona internetowa EUWT Novum, http://www.euwt-novum.eu (15.06.2019).

Strona internetowa EUWT Tritia, http://www.egtctritia.eu/pl (15.06.2019).

Studzieniecki T., Mazurek T., 2018, European Union Funds in the development of European Groupings of Territorial Cooperation (EGTCS) in Europe, European Journal of Service Management, 27 (2), 3, s. 415-424.

Śliz A., Szczepański M.S., 2016, Pogranicze polsko-czeskie w perspektywie socjologicznej. Kontekst kulturowy, Pogranicze. Studia Społeczne, 27, 1, s. 47-59. 
Vaishar A., Dvořák P., Hubačíková V., Zapletalová J., 2013, Contemporary development of peripheral parts of the Czech-Polish borderland: Case study of the Javornik area, Geographia Polonica, 86, 3, s. 237-253.

Więckowski M., 2010, Tourism development in the borderlands of Poland, Geographia Polonica, 83, 2, s. 67-81.

Więckowski M., 2013, Eco-frontier in the mountainous borderlands of Central Europe. The case of Polish border parks, Journal of Alpine Research/Revue de géographie alpine, 101, 2.

Więckowski M., 2018, Political borders under ecological control on the Polish borderlands, Geographia Polonica, 91, 1, s. 127-138.

\section{Summary}

The social and political transitions taking place in Central and Eastern Europe post-1989 allowed Poland to develop cross-border cooperation with neighbouring counties. At local-government level in particular, the Czech Republic then became a key partner. Today, the Polish-Czech borderland resembles those between Poland and Germany, and between Poland and Slovakia, in constituting a model example of innovative cross-border cooperation. While the area first played hosted to Euroregions, it later also fell within European Groupings of Territorial Cooperation. And while collaboration between one local authority and another over the border has evolved particularly dynamically, as-yet untapped potential would seem to remain.

Overall, this article seeks to analyse the actors currently operating across the Polish-Czech border, from a political-science perspective. These are Euroregions (of Nysa, Glacensis, Pradziad, Silesia, Cieszyn Silesia and the Beskids), as well as European Groupings of Territorial Cooperation (of Tritia and Novum), and selected units at local government level. The analysis of the transboundary entities, and those engaging in cross-border activity was of a genetic, structural and functional nature, and this facilitated the identification of similarities and differences between the actors concerned, making clear what their specifics are, and what the prospects for cooperation. 